\title{
Influence of Heat Transfer on Gas Turbine Performance
}

\author{
Diango A., Périlhon C., Danho E. and Descombes G. \\ Laboratoire de génie des procédés pour l'environnement, \\ l'énergie et la santé Conservatoire national des arts et métiers, \\ Paris \\ France
}

\section{Introduction}

In the current economic and environmental context dominated by the energy crisis and global warming due to the $\mathrm{CO}_{2}$ emissions produced by industry and road transportation, there is an urgent need to optimize the operation of thermal turbomachinery in general and of gas turbines in particular. This requires exact knowledge of their typical performance.

The performance of gas turbines is usually calculated by assuming an adiabatic flow, and hence neglecting heat transfer. While this assumption is not accurate for high turbine inlet temperatures (above $800 \mathrm{~K}$ ), it provides satisfactory results at the operating point of conventional machines because the amount of heat transferred is generally low (less than $0.5 \%$ of thermal energy available at the turbine inlet). Internal and external heat transfer are therefore neglected and their influence is not taken into account.

However, current heating needs and the decentralized production of electrical energy involve micro Combined Heat and Power (CHP) using micro-gas turbines (20-250 kW).

In aeronautics, the need for a power source with a high energy density also contributes to interest in the design of ultra-micro gas turbines.

These ultra and micro machines, which operate on the same thermodynamic principles as large gas turbines, cannot be studied with the traditional adiabatic assumption, as has been underlined by many authors such as Ribaud (2004), Moreno (2006) and Verstraete et al. (2007). During operation, heat is transferred from the turbine to the outside, bearing oil, casing and compressor, thus heating the compressor and leading to a drop in turbine performance. Consequently, the performances reported on the maps developed under the adiabatic assumption are no longer accurate.

This chapter presents:

- The influence of heat transfer on the performance at an adiabatic operating point of a gas turbine, and a method for determining the actual operating point knowing the amount of heat transfer.

- A study of heat loss versus the geometry scale of the volute and some conclusions concerning the limits of validity of the adiabatic assumption. 


\section{Relocating an adiabatic operation point subjected to heat transfer on a gas turbine map}

\subsection{Introduction}

The performance of a turbomachine is usually represented graphically with dimensionless coordinates obtained under the assumption of adiabaticity from an existing machine.

These maps are employed by manufacturers and users to determine the overall performance in order to design a new machine or to use the same machine in different operating conditions. The results obtained are not always accurate, however, as this assumption is not valid in all circumstances. Under the influence of heat transfer, the supposedly adiabatic operating point may shift its position. The dimensionless coordinates change, making it necessary to find the actual values for a correct assessment of performance.

In order to simulate the movement of an adiabatic operating point subjected to heat transfer, we consider the single-shaft gas turbine with a simple cycle; the maps are shown in Fig. 13 (Pluviose 2005).

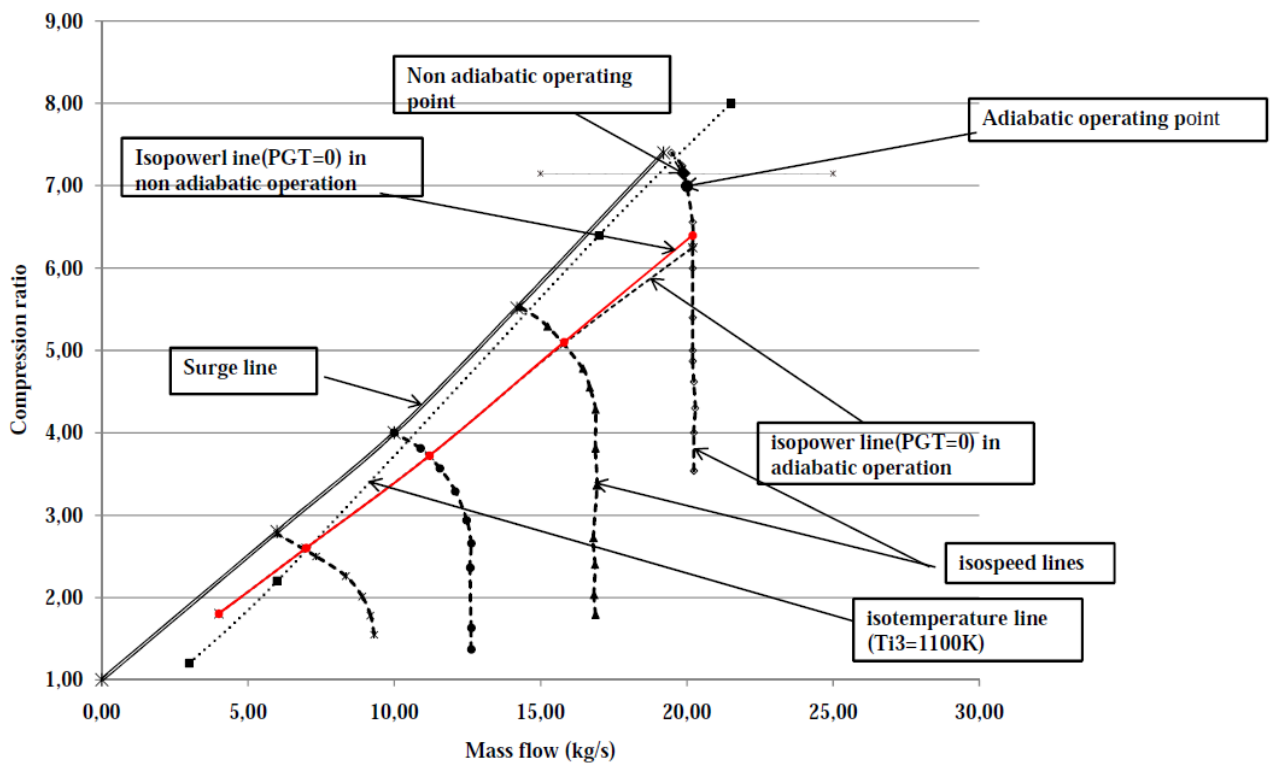

Fig. 1. Adiabatic compressor map of the gas turbine studied (Pluviose, 2005) 


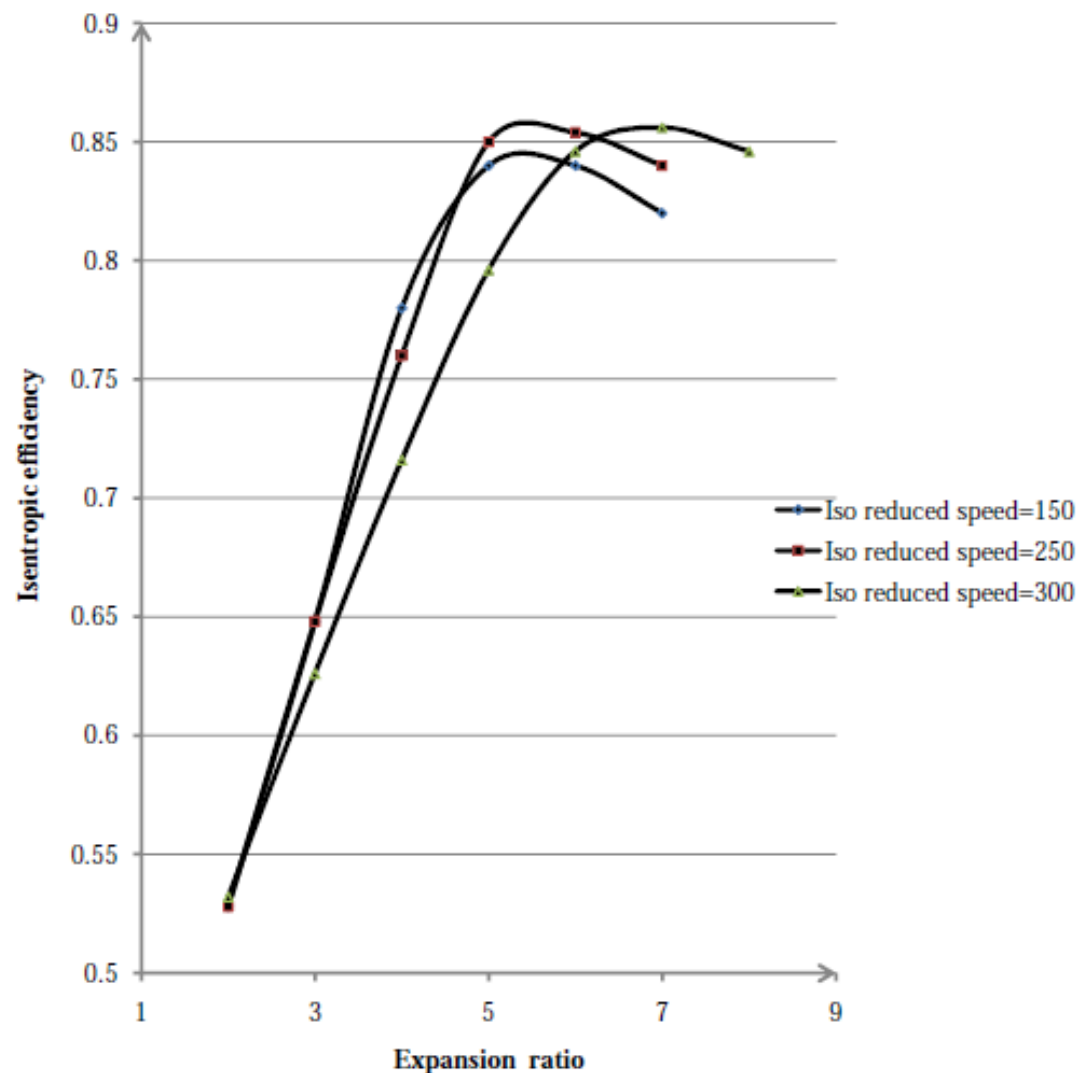

Fig. 2. Isentropic efficiency versus expansion ratio of the turbine (Pluviose, 2005) 


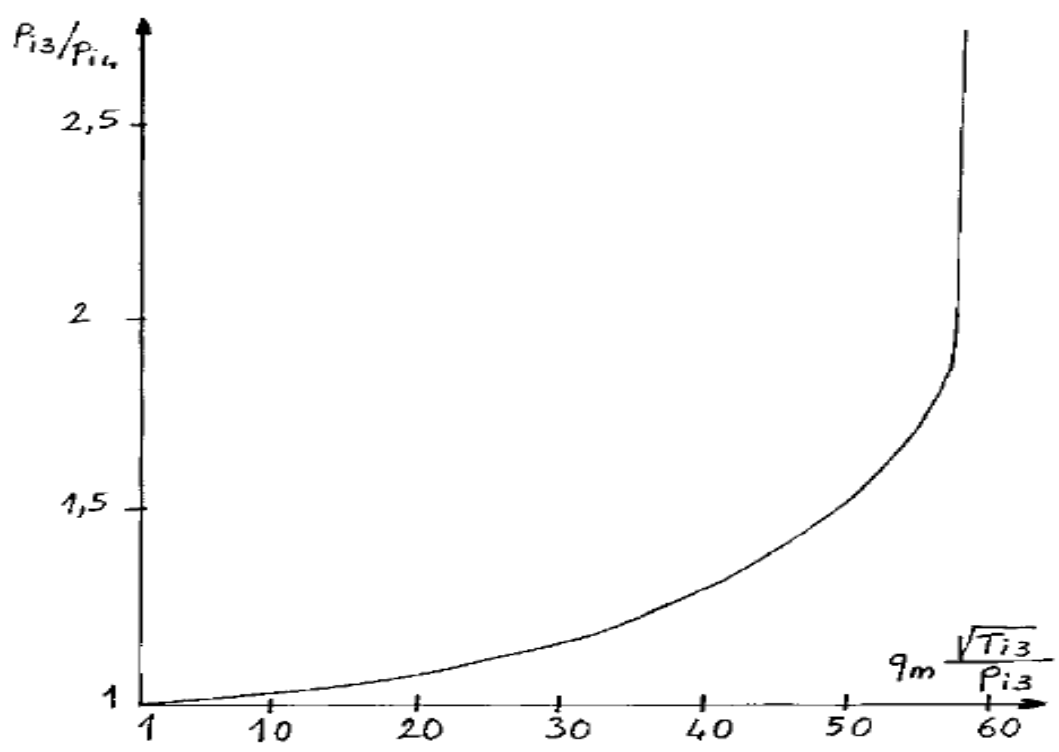

$\mathrm{P}_{\mathrm{i} 3}$ : turbine inlet pressure;

$\mathrm{P}_{\mathrm{i}}$ : turbine outlet pressure;

$\mathrm{T}_{\mathrm{i} 3}$ : turbine inlet temperature;

$\mathrm{T}_{\mathrm{i} 4}$ : turbine outlet temperature.

Fig. 3. Expansion ratio versus dimensionless mass flow rate (Pluviose, 2005)

\subsection{Adiabatic, insulated and non insulated gas turbine versions}

In its simplest form, as shown in Fig. 4, a gas turbine consists of:

- A centrifugal or axial air compressor;

- A combustion chamber in which a mixture of air and fuel is burnt;

- A centripetal or axial turbine;

- A user device (alternator, pumps, etc.).

Neglecting the kinetic and potential energy, the formulation of the first law of thermodynamics in an open system applied to turbomachinery (compressor and turbine) is written:

In transient conditions:

$$
d h=\delta w+\delta q
$$

In steady conditions:

$$
\Delta h=w+q
$$

dh: elementary variation of enthalpy;

ठw: elementary work exchanged;

Sq: elementary amount of heat exchanged with the surroundings;

$\Delta \mathrm{h}$ : specific enthalpy variation;

w: specific work exchanged by the fluid with the moving parts of the machine;

q: heat exchanged by the fluid with its surroundings. 


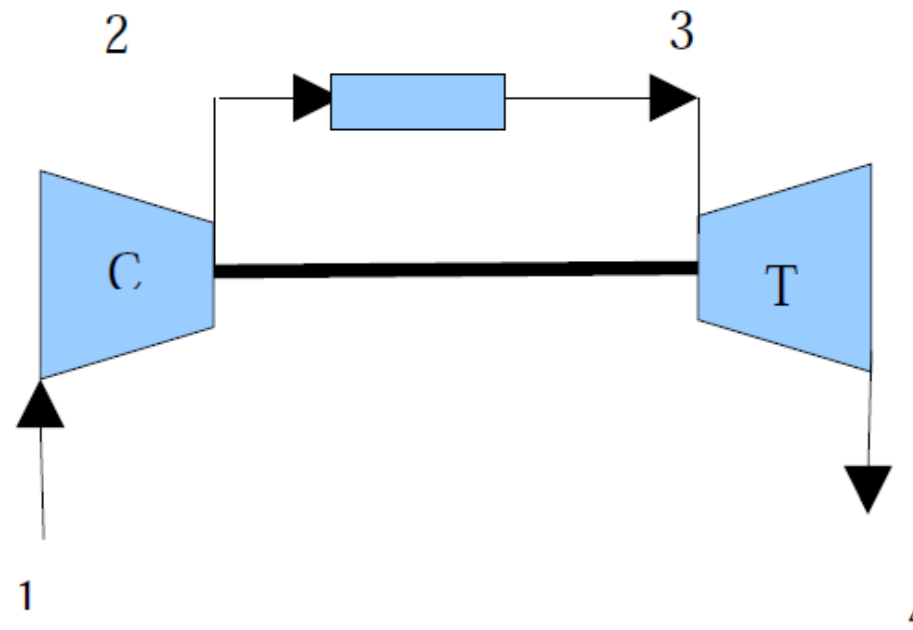

Fig. 4. Simple-cycle, open flow, single-shaft gas turbine

In conventional machines, calculations are usually done by assuming that the gas turbine is adiabatic $(\mathrm{q}=0)$.

The adiabatic version of a gas turbine is one in which the heat exchanged by the fluid with surroundings in the turbomachine is exactly zero (compressor: $\mathrm{q}_{12}$; turbine: $\mathrm{q}_{34}$ ). This version cannot be obtained in practice because of the difference in temperature between the turbine inlet and the surroundings. In order to approximate this ideal configuration, experimenters introduce some thermal insulation. This leads to the concept of insulated and non-insulated gas turbines.

In an insulated gas turbine, the fluid in the turbomachine is assumed not to exchange thermal energy with the surroundings. In practice, this is achieved by insulating the machines with very low thermally conductive materials. However, because of the external insulation, internal heat exchange (in particular from the turbine to the compressor) is increased and must be taken into account.

The non insulated gas turbine is equivalent to one in which internal and external heat transfer coexist.

\subsection{Characteristics of the nominal operating point of an adiabatic gas turbine (Pluviose, 2005)}

The assumptions are:

- $\quad$ Power of mechanical losses: $\mathrm{P}_{\mathrm{ml}}=66 \mathrm{~kW}$;

- $\quad$ Turbine inlet temperature: $\mathrm{T}_{\mathrm{i} 3}=973 \mathrm{~K}$;

- Isentropic efficiency of the turbine: $\eta_{\mathrm{T}}=0.85$;

- $\quad$ Rotational speed : N=8000 rpm;

- The compressor mass flow rate: $\mathrm{q}_{\mathrm{m}}: 20 \mathrm{~kg} \cdot \mathrm{s}^{-1}$;

- Inlet conditions : $\mathrm{p}_{\mathrm{i} 1}=1.013$ bar et $\mathrm{T}_{\mathrm{i} 1}=288 \mathrm{~K}$;

- Specific heat at constant air pressure: $\mathrm{c}_{\mathrm{p}}=1 \mathrm{~kJ} / \mathrm{kg}$

- Specific heat at constant pressure of the burnt gas: $\mathrm{c}_{\mathrm{p}}=1.13 \mathrm{~kJ} / \mathrm{kg}$ 
- $\quad$ Compression ratio : $\pi_{\mathrm{c}}=7$;

- Isentropic efficiency of the compressor : $\eta_{C}=0.8$;

- Pressure drop in combustion chamber: 5\%;

- $\quad$ Specific heat ratios : for air $\gamma=1.4$; for burnt gas $\gamma=1.33$;

- Turbine outlet pressure: $p_{i 4}=1.05$ bar.

The characteristics of the operating point of the adiabatic gas turbine are summarized in Table 1.

\begin{tabular}{|c|c|c|c|c|c|c|c|}
\hline & $\underset{\left(\mathrm{kg} \cdot \mathrm{s}^{-1}\right)}{\mathrm{q}_{\mathrm{m}}}$ & $\begin{array}{c}\pi_{\mathrm{C}} \text { or } \\
\pi_{\mathrm{T}}\end{array}$ & $\begin{array}{c}\mathrm{N} \\
(\mathrm{rpm})\end{array}$ & $\begin{array}{l}\mathrm{P}_{\mathrm{GT}} \\
(\mathrm{kW})\end{array}$ & $\begin{array}{l}\mathrm{T}_{\mathrm{i} 3} \\
(\mathrm{~K})\end{array}$ & $\begin{array}{c}\mathrm{Q}_{\mathrm{cc}} \\
(\mathrm{kW})\end{array}$ & $\begin{array}{c}\eta_{\mathrm{GT}} \\
\%\end{array}$ \\
\hline $\begin{array}{c}\text { Adiabatic } \\
\text { compressor }\end{array}$ & 20 & 7 & 8000 & \multirow{2}{*}{1526.4} & \multirow{2}{*}{973} & \multirow{2}{*}{9431} & \multirow{2}{*}{16.2} \\
\hline $\begin{array}{l}\text { Adiabatic } \\
\text { turbine }\end{array}$ & 20 & 6.42 & 8000 & & & & \\
\hline
\end{tabular}

Table 1. Characteristics of the operating point of an adiabatic gas turbine

The energy balance at the operating point is shown in Table 2 (see the detailed calculations in the appendix).

\begin{tabular}{|l|c|c|}
\hline \multirow{2}{*}{} & \multicolumn{2}{|c|}{ Energy balance } \\
\cline { 2 - 3 } & $\mathrm{kW}$ & $\%$ \\
\hline Thermal power provided by fuel & 9430.7 & 100 \\
\hline Gas Turbine power & 1526.2 & 16.2 \\
\hline Thermal power loss at exhaust & 7838.5 & 83.12 \\
\hline Mechanical losses & 66 & 0.7 \\
\hline Thermal losses & 0 & 0 \\
\hline
\end{tabular}

Table 2. Energy balance at the operating point of the adiabatic gas turbine

\subsection{Characteristics of the nominal operating point of a non-adiabatic gas turbine}

As indicated in section 2.2, there are two non-adiabatic versions of the gas turbine: the insulated and the non-insulated version.

\subsubsection{Influence of heat transfer on the adiabatic nominal operating point}

In order to understand the influence of heat transfer on the nominal operating point, we assume that the turbine is cooled so that the heat losses account for $15 \%$ of the adiabatic work.

For the non-insulated version, $60 \%$ of these losses are considered to contribute to the heating of the compressor (Rautenberg \& al. 1981).

In the insulated version, it is assumed that all the heat lost by the turbine is received by the air in the compressor.

In this study, the amount of heat exchanged is assumed known. The internal work depends on the outlet temperature. In practice, during operation, the outlet temperature of the machine can be measured. But, here, we choose $\mathrm{T}_{\mathrm{i} 2}>\mathrm{T}_{\mathrm{i} 2 \mathrm{ad}}$ (compressor) and $\mathrm{T}_{\mathrm{i} 4 \mathrm{is}}<\mathrm{T}_{\mathrm{i} 4}<\mathrm{T}_{\mathrm{i} 4 a d}$ (turbine).

Table 3 and Table 4 summarize the new performances calculated for the adiabatic gas turbine used in insulated and non-insulated versions at the adiabatic operating point. 


\begin{tabular}{|l|c|c|c|c|c|c|c|}
\hline & $\begin{array}{c}\mathrm{q}_{\mathrm{m}} \\
\left(\mathrm{kg}^{-1}\right)\end{array}$ & $\begin{array}{c}\pi_{\mathrm{C}} \text { ou } \\
\pi_{\mathrm{T}}\end{array}$ & $\begin{array}{c}\mathrm{N} \\
(\mathrm{rpm})\end{array}$ & $\begin{array}{c}\mathrm{P}_{\mathrm{GT}} \\
(\mathrm{kW})\end{array}$ & $\begin{array}{c}\mathrm{T}_{\mathrm{i} 3} \\
(\mathrm{~K})\end{array}$ & $\begin{array}{c}\text { Qcc } \\
(\mathrm{kW})\end{array}$ & $\begin{array}{c}\eta_{\mathrm{GT}} \\
\%\end{array}$ \\
\cline { 1 - 5 } Heated compressor & 20 & 7 & 8000 & \multirow{2}{*}{1128} & 973 & 8521 & 13.2 \\
\hline
\end{tabular}

Table 3. Characteristics of nominal operating point in non insulated version

\begin{tabular}{|l|c|c|c|c|c|c|c|}
\hline & $\begin{array}{c}\mathrm{q}_{\mathrm{m}} \\
\left(\mathrm{kg}^{-1}\right)\end{array}$ & $\begin{array}{c}\pi_{\mathrm{C}} \text { ou } \\
\pi_{\mathrm{T}}\end{array}$ & $\begin{array}{c}\mathrm{N} \\
(\mathrm{rpm})\end{array}$ & $\begin{array}{c}\mathrm{P}_{\mathrm{GT}} \\
(\mathrm{kW})\end{array}$ & $\begin{array}{c}\mathrm{T}_{\mathrm{i} 3} \\
(\mathrm{~K})\end{array}$ & $\begin{array}{c}\text { Qcc } \\
(\mathrm{kW})\end{array}$ & $\begin{array}{c}\eta_{\mathrm{GT}} \\
\%\end{array}$ \\
\cline { 1 - 7 } Heated compressor & 20 & 7 & 8000 & \multirow{2}{*}{1010.38} & 973 & 7917 & 12.8 \\
\hline
\end{tabular}

Table 4. Characteristics of nominal operating point in insulated version

The comparison of the results in Table 1, Table 3 and Table 4, leads to the following comments:

- $\quad$ Energy efficiency has dropped from 16.2 to $13.2 \%$ (Table 1 and Table 3), and from 16.2 to $12.8 \%$ (Table 1 and Table 4 );

- Net power of the gas turbine has decreased from 1526 to $1128 \mathrm{~kW}$, or by $26 \%$ (Table 1 and Table 3); from 1526 to $1010 \mathrm{~kW}$, or by $34 \%$ (Table 1 and Table 4);

We can therefore conclude that if the gas turbine operates with heat transfer while maintaining the same parameters as under nominal adiabatic operation, there is a drop in performance.

This significant drop in performance makes it necessary to determine the actual operating point, taking into account heat transfer and the needs of user devices. For example, in a power plant equipped with a gas turbine, meeting the needs of the consumer requires that the power be kept constant. This involves finding the new non-adiabatic operating point which fulfills this criterion (same power at constant rotational speed).

\subsubsection{Search for a new operating point able to provide the same power}

Search for the new operating point of the compressor

The gas turbine operates under adiabatic or non-adiabatic conditions at $8000 \mathrm{rpm}$. For this speed, the output power is plotted versus the compression ratio in the three configurations: adiabatic, insulated and non-insulated versions (Figure 5).

For the selected power value, the new compression ratios in insulated and non-insulated operation can be deduced. Then drawing this pressure ratio on the compressor map (Fig. 6), the mass flow rate and the efficiency of this point are deduced.

\section{Comments:}

It can be seen on Figure 5 that for the same compression ratio, the net output power is low in the insulated version. The highest output power is obtained in the adiabatic version.

For the same power, the compression ratio is low in the non-insulated version. The lowest value is obtained in the adiabatic version.

\section{Search for the new operating point of the turbine}

As the rotational speed is constant and imposed, the required power can be achieved only by means of the quantity of injected fuel which has a direct influence on $\mathrm{T}_{\mathrm{i} 3}$ (turbine inlet temperature). 


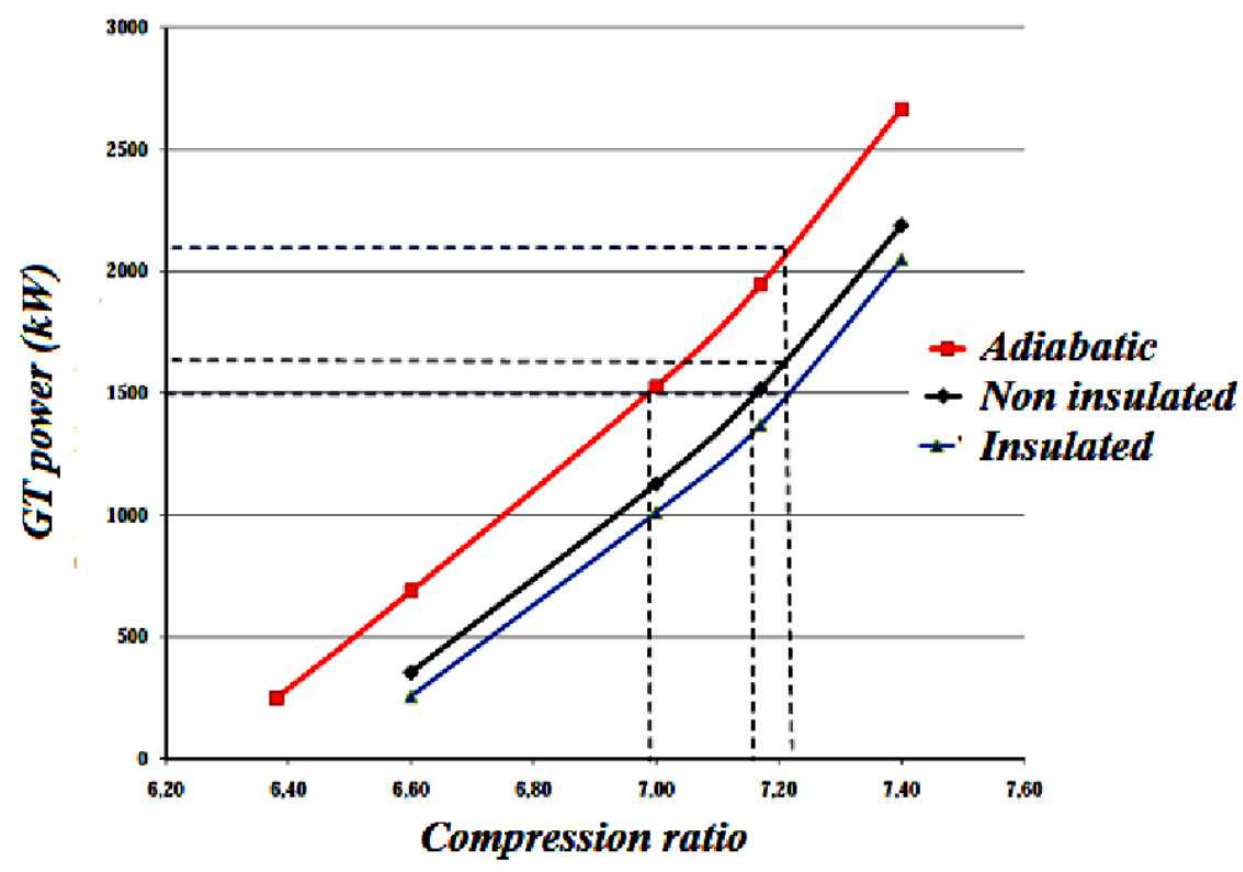

Fig. 5. Output power of the gas turbine versus compression ratio in adiabatic, non-insulated and insulated version

Due to the turbine characteristics, for a pressure ratio above that shown in Fig.3, the reduced mass flowing through the turbine is a constant which was calculated for the nominal operating point in adiabatic conditions (Pluviose, 2005). A reduced mass flow makes it possible to determine the new value of $T_{i 3}$ corresponding to the new pressure $p_{i 3}$.

$$
q_{m} \frac{\sqrt{T_{i 3}}}{p_{i 3}}=c s t
$$

$\mathrm{q}_{\mathrm{m}}$ : mass flow rate $\left(\mathrm{kg} \cdot \mathrm{s}^{-1}\right)$;

$\mathrm{T}_{\mathrm{i} 3}$ : turbine inlet temperature $(\mathrm{K})$;

$\mathrm{p}_{\mathrm{i} 3}$ : turbine inlet pressure $\left(\mathrm{p}_{\mathrm{a}}\right)$.

\section{Non-insulated gas turbine}

The characteristics of the new operating points are summarized in table 5 (see calculations in the appendix).

Comparing the results of Table 1 to Table 5, it can be observed that:

- The mass flow rate has decreased. It varies from 20 to $19.8 \mathrm{~kg}^{-1}$. The relative deviation is $1 \%$;

- The compression ratio has increased from 7 to 7.17 with a relative deviation of $2.4 \%$;

- The turbine inlet temperature has risen from 973 to $1041 \mathrm{~K}$. The maximum is $1100 \mathrm{~K}$;

- The energy efficiency has decreased to 16.2 à $15.6 \%$ (the relative deviation is $3.7 \%$ ). 


\begin{tabular}{|c|c|c|c|c|c|c|c|}
\hline & $\begin{array}{c}\mathrm{q}_{\mathrm{m}} \\
\left(\mathrm{kg} \cdot \mathrm{s}^{-1}\right)\end{array}$ & $\begin{array}{c}\pi_{\mathrm{C}} \text { ou } \\
\pi_{\mathrm{T}}\end{array}$ & $\begin{array}{c}\mathrm{N} \\
(\mathrm{rpm})\end{array}$ & $\begin{array}{c}\mathrm{P}_{\mathrm{GT}} \\
(\mathrm{kW})\end{array}$ & $\begin{array}{c}\mathrm{T}_{\mathrm{i} 3} \\
(\mathrm{~K})\end{array}$ & $\begin{array}{c}\mathrm{Q}_{\mathrm{cc}} \\
(\mathrm{kW})\end{array}$ & $\begin{array}{c}\eta_{\mathrm{GT}} \\
\%\end{array}$ \\
\hline Heated compressor & 19.8 & 7.17 & 8000 & \multirow{2}{*}{1526.2} & 1040.6 & 9764 & 15.6 \\
\hline Cooled turbine & 19.8 & 6.57 & 8000 & &
\end{tabular}

Table 5. Characteristics of the new operating point in the non-insulated version

\section{Insulated gas turbine}

In order to simplify calculations, we consider that all the heat lost by the turbine is fully received by the compressor

\begin{tabular}{|c|c|c|c|c|c|c|c|}
\hline & $\begin{array}{c}\mathrm{q}_{\mathrm{m}} \\
\left(\mathrm{kg} \cdot \mathrm{s}^{-1}\right)\end{array}$ & $\begin{array}{c}\pi_{\mathrm{C}} \text { ou } \\
\pi_{\mathrm{T}}\end{array}$ & $\begin{array}{c}\mathrm{N} \\
(\mathrm{rpm})\end{array}$ & $\begin{array}{c}\mathrm{P}_{\mathrm{GT}} \\
(\mathrm{kW})\end{array}$ & $\begin{array}{c}\mathrm{T}_{\mathrm{i} 3} \\
(\mathrm{~K})\end{array}$ & $\begin{array}{c}\mathrm{Q}_{\mathrm{cc}} \\
(\mathrm{kW})\end{array}$ & $\begin{array}{c}\eta_{\mathrm{GT}} \\
\%\end{array}$ \\
\hline Heated compressor & 19.5 & 7.22 & 8000 & \multirow{2}{*}{1526.2} & 1088 & 10253 & 14.9 \\
\hline Cooled turbine & 19.5 & 6.62 & 8000 & & 152 \\
\hline
\end{tabular}

Table 6. Characteristics of the new operating point in the insulated version

When the results of tables 1 and 6 are compared, it can be seen that:

- The mass flow rate has decreased from 20 to $19.5 \mathrm{~kg} . \mathrm{s}^{-1}$. The relative deviation is $2.5 \%$;

- The compression ratio has increased from 7 to 7.22 . The relative increase is $3.14 \%$;

- $\quad$ The turbine inlet temperature has increased from 973 to $1088 \mathrm{~K}$. The limit is $1100 \mathrm{~K}$;

- The energy efficiency has dropped from 16.2 to $14.9 \%$ (the relative deviation is $8.02 \%$ ).

Overall in the two operating configurations, the operating area on the compressor map has slightly narrowed.

However, the temperature increase can be a problem, as this value has a direct influence on the turbine life span.

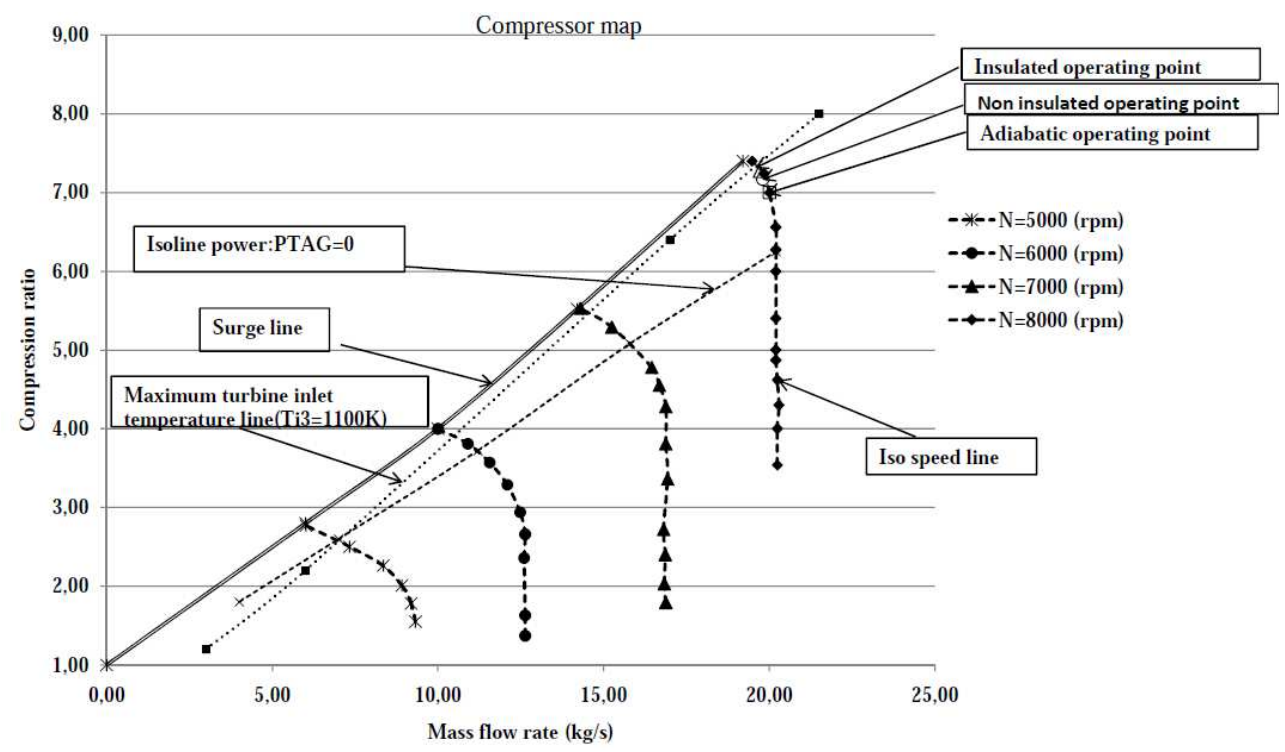

Fig. 6. Adiabatic compressor map with operating points in the three configurations 


\subsubsection{Energy balance of new operating points}

\section{Non-insulated gas turbine}

\begin{tabular}{|l|c|c|}
\hline \multirow{2}{*}{} & \multicolumn{2}{|c|}{ Energy balance } \\
\cline { 2 - 3 } & $\mathrm{kW}$ & $\%$ \\
\hline Calorific power provided by the fuel & 9764 & 100 \\
\hline GT power & 1526.2 & 15.6 \\
\hline Exhaust power & 7129.6 & 73.0 \\
\hline Mechanical losses & 66 & 0.7 \\
\hline Thermal losses & 1042 & 10.7 \\
\hline
\end{tabular}

Table 7. Energy balance of the new operating point (non-insulated gas turbine)

\section{Insulated gas turbine}

\begin{tabular}{|l|c|c|}
\hline \multirow{2}{*}{} & \multicolumn{2}{|c|}{ Energy balance } \\
\cline { 2 - 3 } & $\mathrm{kW}$ & $\%$ \\
\hline Calorific power provided by the fuel & 10253 & 100 \\
\hline GT power & 1526.2 & 14.9 \\
\hline Exhaust power & 7618.8 & 74.3 \\
\hline Mechanical losses & 66 & 0.6 \\
\hline Thermal losses & 1042 & 10.2 \\
\hline
\end{tabular}

Table 8. Energy balance of the new operating point (insulated gas turbine)

Comparing tables 7 and 8 , we can see that at iso speed and iso net power produced, the efficiency of the gas turbine is better in the non-insulated version.

\subsection{Comparison with experimental results}

The analysis and the results presented above for the nominal operating point were extended to the other points of the working area.

Figure 8 shows the experimental results obtained by Moreno (2006) on a small gas turbine $(75 \mathrm{~kW})$.

The tests were carried out in two versions: an insulated version at $39000 \mathrm{rpm}$ and a noninsulated one at $40000 \mathrm{rpm}$. It may be noted that the speeds are not identical because of the practical difficulties of measurement in testing. But the relative difference of $2.5 \%$ between these two speeds can be considered negligible.

Figure 9 shows that, as in the case of our study, iso-speed, iso net power produced by the gas turbine, and energy efficiency are better in the insulated than in the non-insulated version. 


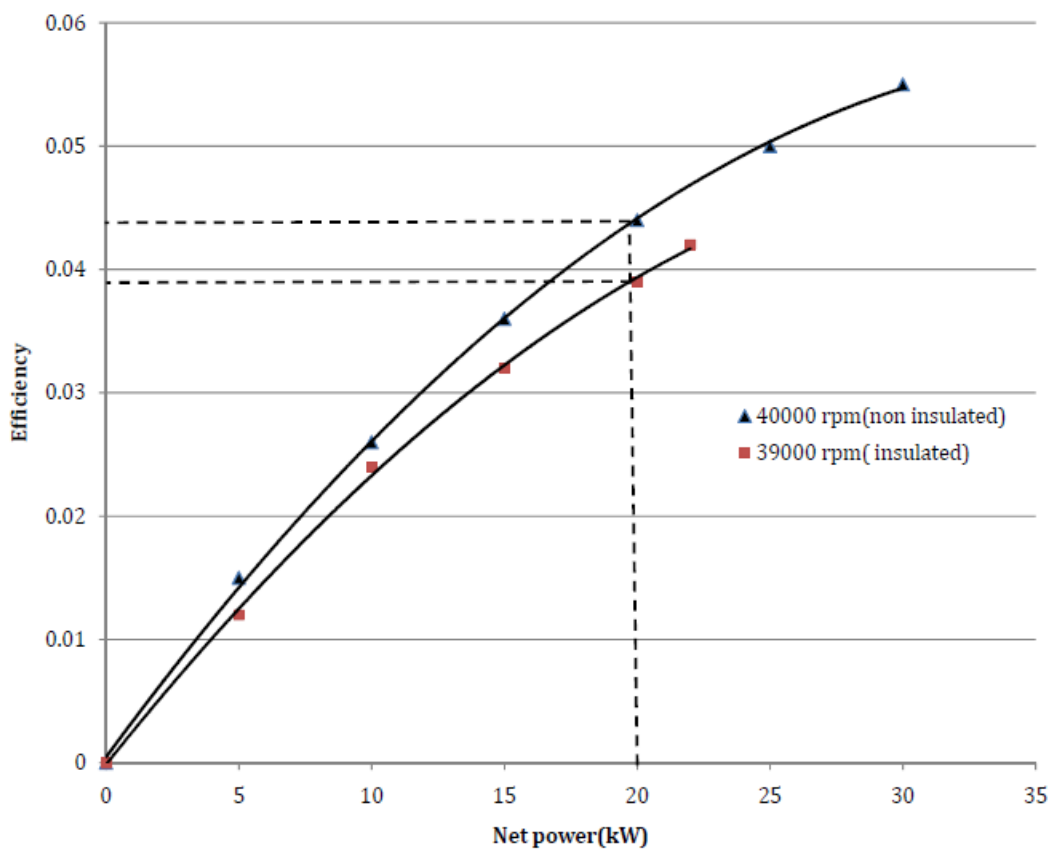

Fig. 7. Energy efficiency versus net power produced (Moreno, 2006)

This study not only confirms the decrease in performance due to heat losses, but also that this drop in performance is proportionally greater with the internal heat transfer.

Compared with the gas turbine studied here $(1500 \mathrm{~kW})$, it can be seen that the energy efficiency of the gas turbine used by Moreno $(75 \mathrm{~kW})$ is very low: $8 \%$ vs $16 \%$ at nominal power. This can be attributed to the size of the machine: it is a small machine with a nominal power about approximately twenty times smaller. Heat losses could be the cause of the drop in performance.

\section{Heat transfer and geometric scale of gas turbines}

As already mentioned in the introduction, the results of the performance calculations carried out in conventional turbomachines remain satisfactory at the full load operating point. In addition, the literature indicates that the impact of heat transfer on the performance of small turbomachines is negative. In these circumstances, it is important to know the characteristic size of the machines in which the assumption of adiabaticity is no longer valid.

This study of heat transfer limited only to the volute of machines studied is conducted in similar operating conditions. It therefore calls on the notion of similarity.

\subsection{The similarity of turbomachines: a summary}

Similarity makes it possible, when a physical phenomenon for given operating conditions is known, to predict the same phenomenon for other conditions through laws involving dependent and independent dimensionless variables. Similarity generally focuses on two 
aspects: the geometric aspect that is relative to a family of geometrically similar machines, and the functional aspect that deals with a family of machines with similar operation. These two aspects are simultaneously taken into account.

For adiabatic machines, the dimensionless independent variables used to characterize the similar operating points are (Pluviose, 2005):

- dimensionless mass flow rate

- dimensionless speed.

For adiabatic machines, the dimensionless independent variables used to characterize the similar operating points are (Pluviose, 2005):

- Dimensionless mass flow rate:

$$
\frac{\mathrm{q}_{\mathrm{m}} \sqrt{\mathrm{rT} \mathrm{T}_{\mathrm{i}}}}{\mathrm{p}_{\mathrm{i} 1} \mathrm{R}^{2}}
$$

- Dimensionless rotational speed:

$$
\frac{\mathrm{NR}}{\sqrt{\mathrm{rT}_{\mathrm{i} 1}}}
$$

$\mathrm{q}_{\mathrm{m}}$ : mass flow rate $\left(\mathrm{kg} \cdot \mathrm{s}^{-1}\right)$;

$\mathrm{T}_{\mathrm{i} 1}$ : turbomachine inlet temperature $(\mathrm{K})$;

$\mathrm{p}_{\mathrm{i} 3}$ : turbomachine inlet pressure $\left(\mathrm{p}_{\mathrm{a}}\right)$;

$\mathrm{R}$ : external radius of the rotor a $(\mathrm{m})$;

$\mathrm{r}$ : specific perfect gas constant $\left(\mathrm{J} \cdot \mathrm{kg}^{-1}\right)$.

A study of similarity in non-adiabatic turbomachines operating with compressible fluid, conducted by Diango (2010) led to the generalization of Rateau's theorem. The author shows that these two dimensionless variables are also valid when operating with heat transfer.

From the foregoing and for a judicious comparison of heat exchange in different volutes, it is generally assumed that the fluid flows are similar. This leads to the following assumptions:

- Inlet parameters are the same (pressure and temperature);

- Reynolds numbers are equal;

- The inlet dimensionless velocities are identical;

- The mass flow rate is the same in the volutes.

In the heat transfer equations, only the mass flow rate and the inlet conditions are involved.

For two machines $a$ and $b$, the first and last assumptions imply:

$$
\begin{gathered}
\frac{\mathrm{q}_{\mathrm{ma}} \sqrt{\mathrm{rT}_{\mathrm{i} 1}}}{\mathrm{R}_{a}^{2} \mathrm{p}_{\mathrm{i} 1}}=\frac{\mathrm{q}_{\mathrm{mb}} \sqrt{\mathrm{rT}_{\mathrm{i} 1}}}{\mathrm{R}_{b}^{2} \mathrm{p}_{\mathrm{i} 1}} \Leftrightarrow \mathrm{q}_{\mathrm{mb}}=\frac{\mathrm{q}_{\mathrm{ma}} \mathrm{R}_{b}^{2}}{\mathrm{R}_{a}^{2}} \\
\mathrm{q}_{\mathrm{mb}}=\frac{\mathrm{q}_{\mathrm{ma}} \mathrm{R}_{b}^{2}}{\mathrm{R}_{a}^{2}}
\end{gathered}
$$

$\mathrm{q}_{\mathrm{ma}}$ : mass flow rate of machine a $\left(\mathrm{kg} . \mathrm{s}^{-1}\right)$;

$\mathrm{q}_{\mathrm{mb}}$ : mass flow rate of machine $\mathrm{b}\left(\mathrm{kg}^{\mathrm{s}} \mathrm{s}^{-1}\right)$;

$\mathrm{p}_{\mathrm{i} 1}$ : inlet pressure $\left(\mathrm{p}_{\mathrm{a}}\right)$;

$\mathrm{T}_{\mathrm{i} 1}$ : inlet temperature $(\mathrm{K})$; 
$\mathrm{R}_{\mathrm{a}}$ : external radius of the rotor of machine $\mathrm{a}(\mathrm{m})$;

$\mathrm{R}_{\mathrm{b}}$ : external radius of the rotor of machine $\mathrm{b}(\mathrm{m})$;

$\mathrm{r}$ : specific perfect gas constant (J.kg-1).

Due to the complex geometry of the casing (volute) of turbomachines and the difficulties of calculating heat transfer coefficients, a numerical approach has been adopted.

\subsection{Mathematical modeling of heat transfer in the gas turbine volute}

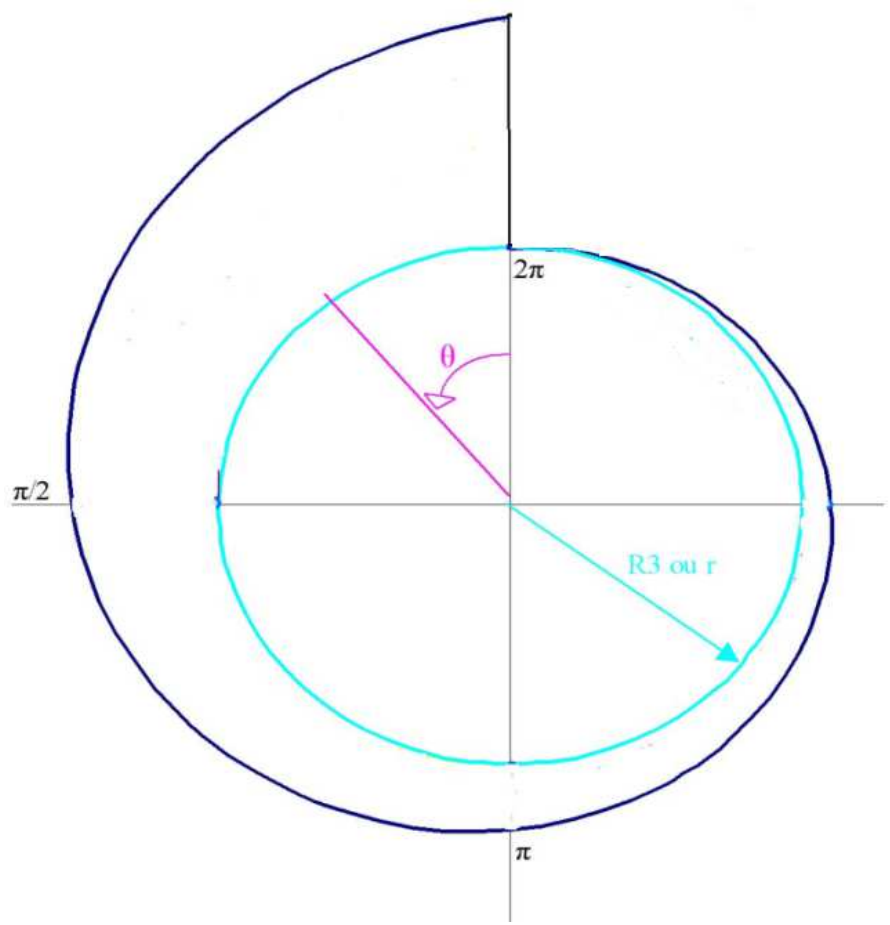

Fig. 8. External shape of the volute

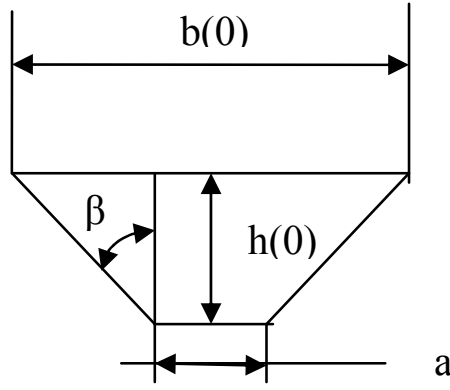

$\mathrm{h}(0)$ : Inlet height (m)

Fig. 9. Inlet section of the volute $(\theta=0)$ 


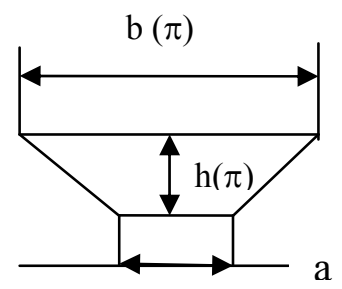

h $(\pi)$ : height at $\theta=\pi$

Fig. 10. Section at $\theta=\pi$

The outer shape is a logarithmic spiral.

\subsubsection{Energy balance on a mesh volume}

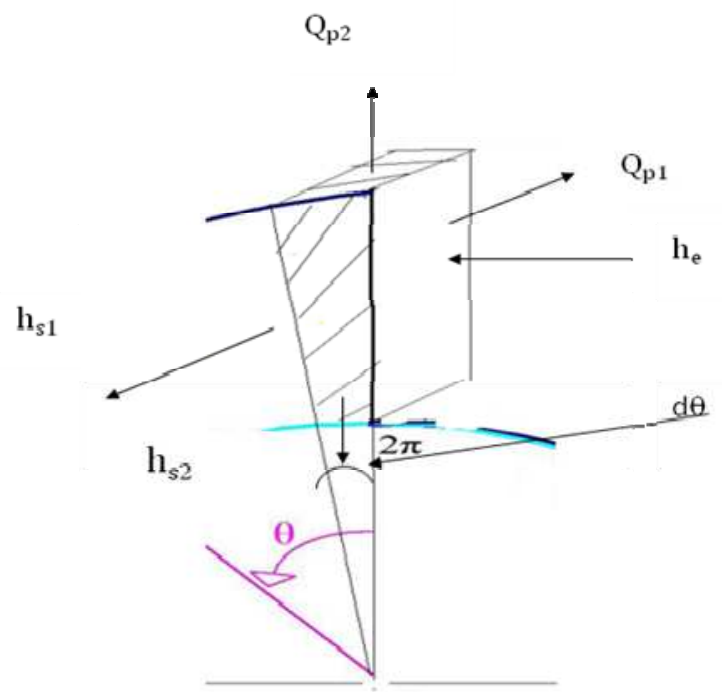

Fig. 11. Mesh volume of the turbine volute

The first law of thermodynamics can be written in any time by the following equation:

$$
\begin{gathered}
\frac{d U}{d t}=\sum_{i} \dot{q}_{i}+\sum_{j} \dot{m}_{j} h_{j}^{*}+\sum_{k} \dot{w}_{k} \\
\mathrm{~h}_{\mathrm{j}}^{*}=\left(\mathrm{h}_{\mathrm{j}}+\frac{\mathrm{v}_{\mathrm{j}}^{2}}{2}+\mathrm{gz} \mathrm{z}_{\mathrm{j}}\right)
\end{gathered}
$$

$\dot{\mathrm{q}}_{i}$ : Heat exchanged by the fluid with surroundings (W); 
$\mathrm{h}_{\mathrm{j}}^{*}$ : Total specific enthalpy of component $\mathrm{j}$ in the mesh volume $\left(\mathrm{J} \cdot \mathrm{kg}^{-1}\right)$;

$h_{j}$ : Specific enthalpy of component $\mathrm{j}$ in the mesh volume $\left(\mathrm{J} . \mathrm{kg}^{-1}\right)$;

$\dot{w_{k}}$ : Mechanical power exchanged by surroundings (W)

$\dot{m}_{j}$ : Flow of material exchanged by the component $\mathrm{j}$ with surroundings $(\mathrm{W})$;

$\frac{v_{j}^{2}}{2}$ : Kinetic energy of component $j$;

$\mathrm{gz}_{\mathrm{j}}$ : Potential energy of component $\mathrm{j}$;

In the volute, the fluid does not exchange mechanical energy with the surroundings, so:

$$
\sum_{k} \dot{w}_{k}=0
$$

Variations in kinetic and potential energy are generally negligible compared to the enthalpy. Equation (5) becomes:

$$
\frac{d U}{d t}=\sum_{i} \dot{q}_{i}+\sum_{j} \dot{m}_{j} h_{j}
$$

In steady state, equation (7) becomes:

$$
\mathrm{q}_{\mathrm{m} \text { in }} \mathrm{h}_{\text {in }}-\mathrm{q}_{\mathrm{m} \text { out } 1} \mathrm{~h}_{\text {out1 } 1}-\mathrm{q}_{\mathrm{m} \mathrm{out} 2} \mathrm{~h}_{\text {out } 2}-\dot{\mathrm{q}}_{\mathrm{w} 1}-\dot{\mathrm{q}}_{\mathrm{w} 2}=0
$$

$\mathrm{q}_{\mathrm{w} 1,2}$ : Heat exchanged through the walls;

$h_{\mathrm{in1,2}}$ : Total specific enthalpy at inlet of the mesh volume (J.kg-1);

$\mathrm{h}_{\text {out1,2 }}$ : Total specific enthalpy at outlet of control volume (J.kg-1);

$\dot{\mathrm{w}}_{\mathrm{k}}$ : Mechanical power exchanged by the fluid with surroundings (W);

$$
\dot{\mathrm{q}}_{\mathrm{p}}=\dot{\mathrm{q}}_{\mathrm{p} 1}+\dot{\mathrm{q}}_{\mathrm{p} 2}
$$

It is assumed in a first approximation that the specific heat of the burnt gas at constant pressure (cpf) does not vary in the mesh volume and that the inlet temperature of gas in the upstream guide is identical to the outlet of the volume vi.

Knowing that:

$$
\mathrm{q}_{\mathrm{m}_{\text {in }}}=\mathrm{q}_{\mathrm{m}_{\text {out1 }}}+\mathrm{q}_{\mathrm{m}_{\text {out2 }}}
$$

Noted henceforth as:

$$
\mathrm{q}_{\mathrm{m}_{\text {in }}}=\mathrm{q}_{\mathrm{m}_{\mathrm{i}-1}}
$$

The expression (8) becomes : 


$$
\begin{gathered}
\mathrm{q}_{\mathrm{m}_{\mathrm{i}-1}} \mathrm{c}_{\mathrm{p}} \mathrm{T}_{\mathrm{i}-1}=\mathrm{q}_{\mathrm{m}_{\mathrm{i}-1}} \mathrm{c}_{\mathrm{p}} \mathrm{T}_{\mathrm{i}}+\dot{\mathrm{q}}_{\mathrm{p}} \\
\dot{q}_{p}=h_{e q} S\left(\mathrm{~T}_{\text {burntgas }}-T_{a}\right)
\end{gathered}
$$

$S:$ Heat exchange surface $\left(\mathrm{m}^{2}\right)$;

$h_{\text {eq }}$ : Equivalent convective heat transfer coefficient $\left(\mathrm{W} \cdot \mathrm{m}^{-2} \cdot \mathrm{K}^{-1}\right)$;

$T_{\text {burnt gas }}$ : Average temperature of the burnt gas in the control volume (K);

$T_{a}$ : Average ambient temperature $(\mathrm{K})$

\subsubsection{Heat exchange surface}

The mesh volume is considered as a tube in which fluid flows. The elementary exchange surface is the area of the contour of the tube, not including the passage through the upstream guide. It is equal to the perimeter multiplied by the elementary length of the spiral.

The equation of the outer profile of the logarithmic spiral volute ranging from 0 to $2 \pi$ is given by equation (11), following Moreno (2006):

$$
R(\theta)=a e^{-b \theta}+c
$$

$R(0), R(\pi)$ and $R(2 \pi)$ : external radius of the volute at $\theta=0 ; \pi$ and $2 \pi(\mathrm{m})$.

Assuming $R(0), R(\pi)$ and $R(2 \pi)$ are known, we can write the following relationships, from Moreno (2006), which describe the outer shape of the volute:

$$
\begin{gathered}
c=\frac{R(2 \pi) R(0)-R^{2}(\pi)}{R(2 \pi)+R(0)-2 R(\pi)} \\
\mathrm{b}=-\frac{1}{2 \Pi} \ln \left[\frac{\mathrm{R}(2 \pi)-\mathrm{c}}{\mathrm{a}}\right] \\
\mathrm{a}=\mathrm{R}(0)-\mathrm{c}
\end{gathered}
$$

a and $b$ : constant real numbers $(\mathrm{m})$

The arc length of the spiral at the position $\theta$ is given by equations (15) and (16), from Berger \& Gostiaux (1992):

$$
\begin{gathered}
L(\theta)=\int_{a}^{b} \sqrt{R^{\prime}(\theta)^{2}+R(\theta)^{2}} d \theta \\
L(\theta)=\int_{u}^{v} \sqrt{a^{2} b^{2} e^{-2 b \theta}+\left(a e^{-b \theta}+c\right)^{2}} d \theta
\end{gathered}
$$




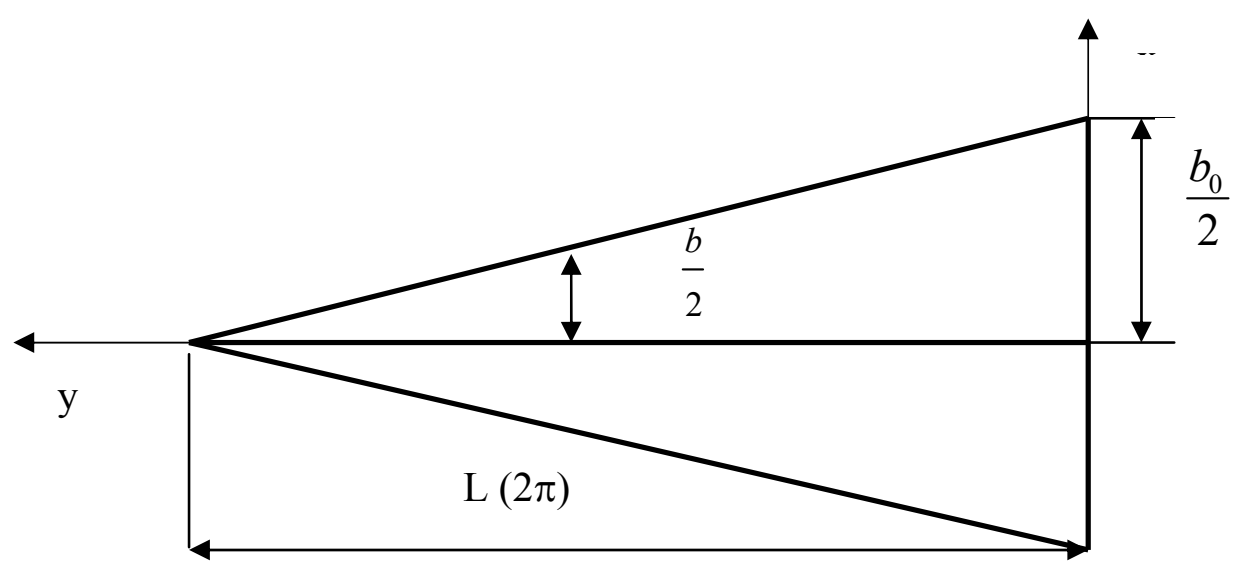

Fig. 12. The width of the upper volute versus the unrolled spiral

The flow section has a trapezoidal shape whose dimensions must be calculated in order to estimate the perimeter.

To determine the large base $\mathrm{b}(\theta \mathrm{i})$, of the trapezium, the equation used is:

$$
b(\theta)=b_{0}\left[1-\frac{L(\theta)}{L(2 \Pi)}\right]
$$

The angle generated by the height and the lateral side (Figure 9, Figure 10) is expressed by:

$$
\operatorname{tg} \beta=\frac{b(\theta)-l_{t n}}{h(\theta)}
$$

$1_{\text {tn: }}$ turbine nozzle width.

The length of the lateral side $\left(\mathrm{L}_{1}\right)$ is:

$$
L_{l}(\theta)=\frac{h(\theta)}{\cos \beta}
$$

Hence the perimeter is:

$$
P(\theta)=2 L_{l}(\theta)+b(\theta)
$$

The heat exchange surface of the mesh volume is then:

$$
\begin{gathered}
d A=P d L=\left[2 L_{l}(\theta)+b(\theta)\right] d L \\
A=\left[2 L_{l}(\theta)+b(\theta)\right] \int_{u}^{v} \sqrt{a^{2} b^{2} e^{-2 b \theta}+\left(a e^{-b \theta}+c\right)^{2}} d \theta
\end{gathered}
$$




\subsubsection{Heat exchange coefficient}

\section{Forced convection inside the volute}

The heat transfer coefficient is given by equation (22)

$$
\mathrm{h}_{f c}(v)=\frac{\mathrm{Nu}\left(v_{i}\right) \lambda_{\text {burnt gas }}}{D_{h}\left(v_{i}\right)}
$$

hfc: coefficient of forced convection ;

$\lambda$ burnt gas: conductivity of burnt gas;

Dh: hydraulic diameter;

vi: mesh volume.

The forced convection model uses the simplified correlation of Sieder \& Tate (Kreith 1967) to calculate the Nusselt number $(\mathrm{Nu})$ from the Prandtl (Pr) and Reynolds (Re) numbers:

$$
\begin{aligned}
& \operatorname{Nu}=0,023 \operatorname{Re}^{0,8} \operatorname{Pr}^{0,3} \\
& \operatorname{Pr}=\frac{\mu_{\text {burnt gas }} C_{\mathrm{p} \mathrm{burnt} \mathrm{gas}}}{\lambda_{\text {burnt gas }}} \\
& \operatorname{Re}\left(v_{i}\right)=\frac{q_{m} D_{h}\left(v_{i}\right)}{\mu_{\text {burnt gas }} S\left(v_{i}\right)}
\end{aligned}
$$

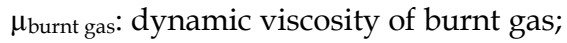

\section{Free convection outside the volute}

The Nusselt number is given by the Morgan correlation (Padet 2005) from the Rayleigh number (Ra).

$$
\begin{gathered}
\overline{N u}=A R_{a}^{n} \\
\mathrm{Ra}=\frac{g \beta \mathrm{D}_{\mathrm{h}}{ }^{3}\left(\mathrm{~T}_{w}-\mathrm{T}_{\mathrm{a}}\right)}{\mathrm{av}_{\mathrm{a}}}
\end{gathered}
$$

$\mathrm{T}_{\mathrm{W}}$ : wall temperature;

$\mathrm{v}_{\mathrm{a}}$ : Kinematic viscosity of the air;

$\mathrm{T}_{\mathrm{a}}$ : air temperature.

The coefficient of external heat exchange is the combination of a coefficient by natural convection and exchange by radiation defined by equation 28 .

$$
h_{a m b}=h_{n c}+h_{r a d}
$$

$\mathrm{h}_{\mathrm{amb}}$ : coefficient of heat exchange with ambient air;

$\mathrm{h}_{\mathrm{nc}}$ : coefficient of heat exchange by natural convection;

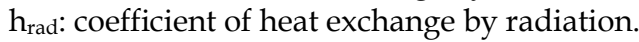


The coefficient of heat exchange by radiation is given by equation (29):

$$
\mathrm{h}_{\mathrm{rad}}\left(\mathrm{v}_{\mathrm{i}}\right)=\frac{\varepsilon \sigma\left(\mathrm{T}_{w}^{4}-\mathrm{T}_{\mathrm{a}}^{4}\right)}{\mathrm{T}_{w}-\mathrm{T}_{\mathrm{a}}}
$$

The equation of the model of mass flow in the volume is (30):

$$
\mathrm{q}_{\mathrm{m} \theta}=\mathrm{q}_{\mathrm{m} 0}\left(1-\frac{\theta}{2 \Pi}\right)
$$

$\mathrm{q}_{\mathrm{m} \theta}$ : the mass flow at position $\theta$;

$\mathrm{q}_{\mathrm{m} 0}$ : the mass flow at position 0 .

\subsection{Numerical results of modeling}

Calculations are started from a nominal operating point of a turbine of a turbocharger whose dimensions are known (see Table 9).

Geometric similarity requires that the linear dimensions of the similar volutes be multiplied by the same factor. Four other turbines have therefore been considered. The main dimensions and corresponding mass flow are recorded in table 10, which also shows the numerical results of the modeling.

\begin{tabular}{|c|c|c|c|}
\hline $\mathrm{T}_{\mathrm{i} 3}(\mathrm{~K})$ & $\begin{array}{c}\mathrm{q}_{\mathrm{m}} \\
\left(\mathrm{kg} \cdot \mathrm{s}^{-1}\right)\end{array}$ & $\mathrm{T}_{\mathrm{w}}(\mathrm{K})$ & $\begin{array}{c}\mathrm{N} \\
(\mathrm{rpm})\end{array}$ \\
\hline 761.3 & 0.848 & 760 & 110000 \\
\hline
\end{tabular}

Table 9. Nominal point of the reference turbine

$$
\mathrm{Q}_{\mathrm{wdim}}=\frac{\mathrm{Q}_{w}}{\mathrm{q}_{\mathrm{m}} \mathrm{C}_{\mathrm{p}} \mathrm{T}_{\mathrm{i} 3}}
$$

$\mathrm{Q}_{\mathrm{w}}$ : Thermal power lost through the walls of the volute;

$\mathrm{Q}_{\mathrm{wdim}}$ : dimensionless thermal power lost through the walls of the volute.

\begin{tabular}{|c|c|c|c|c|c|c|c|}
\hline $\begin{array}{c}\mathrm{R}(0) \\
(\mathrm{m})\end{array}$ & $\begin{array}{c}\mathrm{R}(\pi) \\
(\mathrm{m})\end{array}$ & $\begin{array}{c}\mathrm{R}(2 \pi) \\
(\mathrm{m})\end{array}$ & $\begin{array}{c}\mathrm{b} \\
(\mathrm{m})\end{array}$ & $\begin{array}{c}\mathrm{q}_{\mathrm{m}} \\
\left(\mathrm{kg} \cdot \mathrm{s}^{-1}\right)\end{array}$ & $\begin{array}{c}\frac{S}{V} \\
\left(\mathrm{~m}^{-1}\right)\end{array}$ & $\begin{array}{c}\mathrm{Q}_{W} \\
(\mathrm{~W})\end{array}$ & $\begin{array}{c}\mathrm{Q}_{\text {Wdim }} \\
\mathrm{x} 10^{-4}\end{array}$ \\
\hline 0.03104 & 0.0266 & 0.020325 & 0.017 & 0.0212 & 463 & 202 & 106 \\
\hline 0.04656 & 0.0399 & 0.03049 & 0.0255 & 0.0477 & 308 & 273 & 64 \\
\hline 0.06208 & 0.05321 & 0.04065 & 0.034 & 0.0848 & 231 & 341 & 45 \\
\hline 0.0776 & 0.06651 & 0.05081 & 0.0425 & 0.1325 & 185 & 408 & 34 \\
\hline 0.09312 & 0.07981 & 0.060975 & 0.05099 & 0.1908 & 154 & 474 & 28 \\
\hline
\end{tabular}

Table 10. Heat loss through the volutes of different sizes 
Figures 13 and 14 give the modeling results. Figure 13 shows the evolution of the heat exchange surface versus the inlet radius. The greater the volute, the smaller the surface to volume ratio. Small turbomachines therefore have a higher surface to volume ratio.

The necessity of taking into account heat transfer in small turbomachines is largely confirmed by Figure 14: the heat losses in the volute are relatively greater.

In this study, when the inlet radius is halved, the surface to volume ratio doubles and the heat losses are multiplied by about 2.5

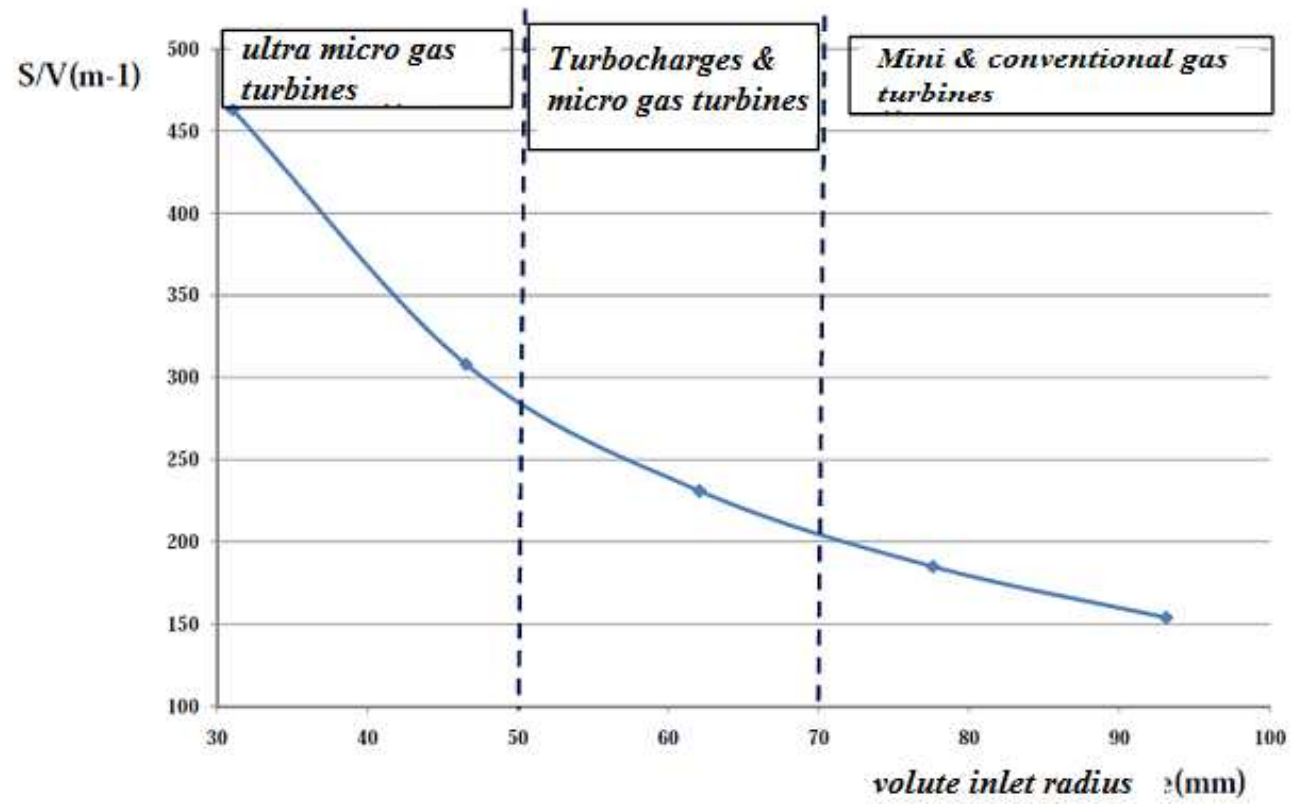

Fig. 13. Ratio of heat exchange surface (S) and the volume (V) of the volute versus the inlet radius 


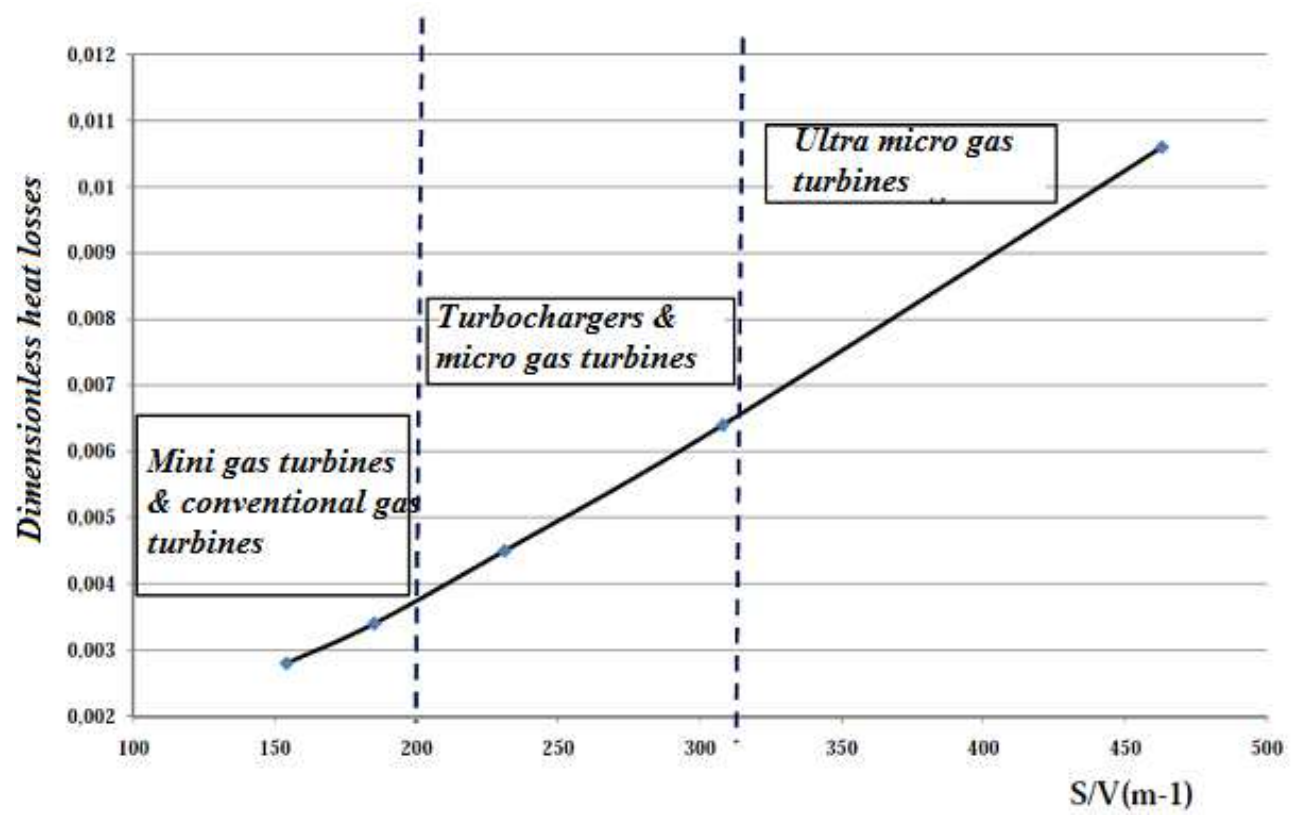

Fig. 14. Heat transfer in the volute versus the size of the machine

\section{Conclusion}

Internal and external heat transfer induces a drop in the performance of gas turbines. This study shows that the performance of small turbomachines evaluated with the assumption of adiabaticity is not accurate.

For a given operating point, the mass flow and the compression ratio recorded on the maps and the calculated performance do not correspond to the actual characteristics when the machine operates with heat transfer.

The assumption that heat losses represent $15 \%$ of the work of adiabatic turbines, of which $60 \%$ is received by the compressor (non-insulated), leads to overestimating the power by $35 \%$ and the energy efficiency by $23 \%$

Insulation of the turbine, although it seems to be a solution to maintain the operating characteristics of adiabatic turbines, leads in fact to increasing the drop in performance.

For the insulated version, the net power is overestimated by $51 \%$ and efficiency by $26.6 \%$. In the absence of an adiabatic gas turbine (ideal machine), which provides the best performance, we must avoid insulating the turbine in order not to decrease performance still further.

To maintain the level of performance, and in particular the net power produced by the gas turbines, despite heat transfer, adjustments are needed. They consist mainly in increasing the fuel flow, resulting in an increase in the turbine inlet temperature. In the case of our study, the fuel flow increase is $3.5 \%$ in the non-insulated version and $8.5 \%$ in the insulated version. The turbine inlet temperature increase is $6.4 \%$ in the insulated version and $11.8 \%$ in the non-insulated version. 
Finally, this study confirms that the assumption of adiabaticity is not valid in turbochargers, micro and ultra-micro gas turbines. Compared to the available thermal energy at the turbine inlet, heat losses increase with the surface to volume ratio which decreases in small-sized machines. The quality of operation of small turbomachinery cannot be characterized with isentropic efficiency which has no physical meaning because of the relative importance of heat transfer.

The proposal of a new performance indicator and the development of new maps available for any type of thermal turbomachines will therefore be the subject of our forthcoming investigations.

\section{Acknowledgment}

The authors would like to acknowledge the French Cooperation EGIDE for funding this study.

\section{Appendix: Energy balance calculations}

\section{Adiabatic gas turbine:}

Data: (see page 6)

Power of the gas turbine: $\mathrm{P}_{\mathrm{GT}}$

Compressor power : Pc

$$
\begin{gathered}
P_{\mathrm{C}}=q_{m} c_{p}\left(T_{i 2}-T_{\mathrm{i} 1}\right) ; \mathrm{T}_{\mathrm{i} 2}=\mathrm{T}_{\mathrm{i} 1}+\left[\left(\frac{\mathrm{p}_{\mathrm{i} 2}}{\mathrm{p}_{\mathrm{i} 1}}\right)^{\frac{\gamma-1}{\gamma}}-1\right] \frac{\mathrm{T}_{\mathrm{i} 1}}{\mathrm{\eta}_{\mathrm{C}}}=288+\left[(7)^{\frac{0,4}{1,4}-1}\right] \frac{288}{0,8}=555.71 \mathrm{~K} \\
P_{\mathrm{C}}=\mathrm{q}_{m} c_{\mathrm{p}}\left(\mathrm{T}_{\mathrm{i} 2}-\mathrm{T}_{\mathrm{i} 1}\right)=20 \times 1(555.71-288)=5354.2 \mathrm{~kW}
\end{gathered}
$$

Turbine power $\mathrm{P}_{\mathrm{T}}$ :

$$
\begin{gathered}
P_{\mathrm{T}}=\mathrm{q}_{m} \mathrm{c}_{\mathrm{p}}\left(\mathrm{T}_{\mathrm{i} 4}-\mathrm{T}_{\mathrm{i} 3}\right) ; \\
\mathrm{T}_{\mathrm{i} 4}=\mathrm{T}_{\mathrm{i} 3}+\left[\left(\frac{\mathrm{p}_{\mathrm{i} 4}}{\mathrm{p}_{\mathrm{i} 3}}\right)^{\frac{\gamma-1}{\gamma}}-1\right] \mathrm{T}_{\mathrm{i} 3} \times \mathrm{\eta}_{\mathrm{T}}=973+\left[\left(\frac{1}{6.42}\right)^{\frac{0.33}{1.33}}-1\right] \times 973 \times 0.85=665.64 \mathrm{~K} \\
P_{\mathrm{T}}=\left|\mathrm{q}_{m} \mathrm{c}_{\mathrm{p}}\left(\mathrm{T}_{\mathrm{i} 4}-\mathrm{T}_{\mathrm{i} 3}\right)\right|=|20 \times 1.13 \times(665.64-973)|=6946.4 \mathrm{~kW} \\
P_{\mathrm{GT}}=P_{T}-P_{\mathrm{C}}-P_{m l}=6946.4-5354.2-66=1526.2 \mathrm{~kW}
\end{gathered}
$$

Thermal power supplied by combustion chamber: $Q_{c c}$

The fuel flow is neglected

$$
Q_{c c}=\mathrm{q}_{m} \mathrm{c}_{\mathrm{p}}\left(\mathrm{T}_{\mathrm{i} 3}-\mathrm{T}_{\mathrm{i} 2}\right)=20 \times 1.13 \times(973-555.71)=9430.7 \mathrm{~kW}
$$


Thermal power lost in the exhaust gas: $Q_{\text {exh }}$

$$
Q_{\text {exh }}=\mathrm{Q}_{C C}-\mathrm{P}_{m l}-\mathrm{P}_{G T}=9430.7-66-1526.2=7838.5 \mathrm{~kW}
$$

\section{Non insulated gas turbine:}

Data: $\pi_{\mathrm{c}}=7.17$ (Figure 6); $\mathrm{q}_{\mathrm{m}}=19.8 \mathrm{~kg} \cdot \mathrm{s}^{-1}$ (From the adiabatic compressor map). $\mathrm{T}_{\mathrm{i} 2}=604.20$ $\mathrm{K} ; \mathrm{Q}_{12}=625.2 \mathrm{~kW}$ (thermal power received by the compressor).

Power of the gas turbine: $\mathrm{P}_{\mathrm{GT}}$

Thermal power received by the compressor: $Q_{12}$

$$
\mathrm{Q}_{12}=0.15 \times 0.6 \times \mathrm{P}_{\mathrm{Tad}}=0.15 \times 0.6 \times 6946.4=625.2 \mathrm{~kW}
$$

$\mathrm{P}_{\text {Tad }}$ : adiabatic turbine power

Compressor power: Pc

$$
\begin{gathered}
\mathrm{h}_{2}-\mathrm{h}_{1}=\frac{\gamma \mathrm{r}}{\mathrm{\gamma}-1}\left(\mathrm{~T}_{\mathrm{i} 2}-\mathrm{T}_{\mathrm{i} 1}\right)=\frac{0.287 \times 1.4}{0.4} \times(604.20-288)=317.62 \mathrm{~kJ} \cdot \mathrm{kg}^{-1} \\
\Delta \mathrm{H}_{12}=\mathrm{q}_{\mathrm{m}}\left(\Delta \mathrm{h}_{12}\right)=317.62 \times 19.8=6288.9 \mathrm{~kW} \\
\mathrm{P}_{\mathrm{C}}=\Delta \mathrm{H}_{12}-\mathrm{Q}_{12}=6288.9-625.2=5663.7 \mathrm{~kW}
\end{gathered}
$$

Turbine power $\mathrm{P}_{\mathrm{T}}$ :

$$
\begin{aligned}
& \mathrm{P}_{\mathrm{GT}}=1526.2 \mathrm{~kW} \\
& \left|\mathrm{P}_{\mathrm{T}}\right|=\mathrm{P}_{\mathrm{GT}}+\mathrm{P}_{\mathrm{C}}+\mathrm{P}_{\mathrm{ml}}=1526.4+5663.7+66=7256.1 \mathrm{~kW}
\end{aligned}
$$

\section{Search for new turbine inlet temperature}

The variation in the expansion ratio of the turbine versus the reduced mass flow (Figure 3 ) shows that when the expansion ratio is greater than two (2), the reduced mass flow remains constant (Pluviose M., 2005). This reduced flow constant calculated in adiabatic conditions enables the new turbine inlet temperature $\left(T_{i 3}\right)$ corresponding to the new pressure $\left(\mathrm{p}_{\mathrm{i} 3}\right)$ to be determined by the following equations.

$$
\left(q_{m} \frac{\sqrt{T_{i 3}}}{p_{i 3}}\right)_{a d}=\left(q_{m} \frac{\sqrt{T_{i 3}}}{p_{i 3}}\right)_{\text {nonins }}=q_{m(\text { reduced })}=\left(20 \times \frac{\sqrt{973}}{6.42 \times 1.05 \times 10^{5}}\right)=92.55 \times 10^{-5}
$$

ad: adiabatic

Non ins: non insulated

$$
\begin{gathered}
p_{\text {i3nonins }}=0.95 \times \pi_{\text {Cnonins }} \times p_{i 1}=0.95 \times 7.17 \times 1.01325=6.902 \text { bars } \\
T_{\text {i3nonins }}=\left(\frac{q_{m(\text { reduced })} \times p_{\text {i3nonins }}}{q_{\text {mnonins }}}\right)^{2}=\left(\frac{92.55 \times 10^{-5} \times 6.902 \times 10^{5}}{19.8}\right)^{2}=1040.6 \mathrm{~K}
\end{gathered}
$$




$$
\begin{gathered}
\mathrm{T}_{\mathrm{i} 4 \text { isentropic }}=\mathrm{T}_{\mathrm{i} 3}\left(\frac{1}{\Pi_{\mathrm{T}}}\right)^{\frac{\gamma-1}{\gamma}}=1041.6 \times\left(\frac{1}{6.57}\right)^{\frac{0.33}{1.33}}=652.90 \mathrm{~K} \\
\mathrm{~T}_{\mathrm{i} 4 \text { non ins }}=671.23 \mathrm{~K}
\end{gathered}
$$

Thermal power supplied by the combustion chamber: $Q_{c c}$

The fuel flow is neglected

$$
Q_{c c}=\mathrm{q}_{m} \mathrm{c}_{\mathrm{p}}\left(\mathrm{T}_{\mathrm{i} 3}-\mathrm{T}_{\mathrm{i} 2}\right)=19.8 \times 1.13 \times(1040.6-604.2)=9764 \mathrm{~kW}
$$

Thermal power lost in the exhaust gas

$$
Q_{e x h}=Q_{C C}-P_{m l}-P_{t h l}-P_{G T}=9764-66-625.2 / 0.6-1526.4=7129.56 \mathrm{~kW}
$$

$\mathrm{P}_{\text {thl }}$ : power of thermal losses .

\section{Insulated gas turbine:}

Data: $\pi_{\mathrm{c}}=7.22$ (Figure 6); $\mathrm{q}_{\mathrm{m}}=19.5 \mathrm{~kg} . \mathrm{s}^{-1}$ (from the adiabatic compressor map). $\mathrm{T}_{\mathrm{i} 2}=622.68$ $\mathrm{K}, \mathrm{Q}_{12}=1042 \mathrm{~kW}$ (thermal power received by the compressor)

Power of the gas turbine: $\mathrm{P}_{\mathrm{GT}}$

Thermal power received by the compressor: $\mathrm{Q}_{12}$

$$
\mathrm{Q}_{12}=0.15 \times \mathrm{P}_{\mathrm{Tad}}=0.15 \times 6946.4=1042 \mathrm{~kW}
$$

$\mathrm{P}_{\text {Tad }}$ : Adiabatic turbine power

Compressor power: $\mathrm{P}_{\mathrm{C}}$

$$
\begin{gathered}
\mathrm{h}_{2}-\mathrm{h}_{1}=\frac{\mathrm{\gamma r}}{\mathrm{\gamma}-1}\left(\mathrm{~T}_{\mathrm{i} 2}-\mathrm{T}_{\mathrm{i} 1}\right)=\frac{0.287 \times 1.4}{0.4} \times(622.68-288)=336.19 \mathrm{~kJ} . \mathrm{kg}^{-1} \\
\Delta \mathrm{H}_{12}=\mathrm{q}_{\mathrm{m}}\left(\Delta \mathrm{h}_{12}\right)=317.62 \times 19.5=6555.6 \mathrm{~kW} \\
\mathrm{P}_{\mathrm{C}}=\Delta \mathrm{H}_{12}-\mathrm{Q}_{12}=6555.6-1042=5513.6 \mathrm{~kW}
\end{gathered}
$$

Turbine power $\mathrm{P}_{\mathrm{T}}$ :

$$
\begin{aligned}
& \mathrm{P}_{\mathrm{TAG}}=\mathrm{P}_{\mathrm{T}}=1526.2 \mathrm{~kW} \\
& \left|\mathrm{P}_{\mathrm{T}}\right|=\mathrm{P}_{\mathrm{TAG}}+\mathrm{P}_{\mathrm{C}}+\mathrm{P}_{\mathrm{ml}}=1526.4+5513.6+66=7105.8 \mathrm{~kW}
\end{aligned}
$$

Search for new turbine inlet temperature

$$
\left(q_{m} \frac{\sqrt{T_{i 3}}}{p_{i 3}}\right)_{a d}=\left(q_{m} \frac{\sqrt{T_{i 3}}}{p_{i 3}}\right)_{\text {ins }}=q_{m(\text { reduced })}=\left(20 \times \frac{\sqrt{973}}{6.42 \times 1.05 \times 10^{5}}\right)=92.55 \times 10^{-5}
$$

ad : adiabatic

$$
p_{i 3 i n s}=0,95 \times \pi_{\text {Cins }} \times p_{i 1}=0.95 \times 7.22 \times 1.01325=6.95 \text { bars }
$$




$$
\begin{gathered}
T_{\text {i3insulated }}=\left(\frac{q_{m(\text { reduced })} \times p_{\text {i3insulated }}}{q_{\text {minsulated }}}\right)^{2}=\left(\frac{92.55 \times 10^{-5} \times 6.95 \times 10^{5}}{19.5}\right)^{2}=1088 \mathrm{~K} \\
\mathrm{~T}_{\mathrm{i}_{4} \text { isentropic }}=\mathrm{T}_{\mathrm{i} 3}\left(\frac{1}{\Pi_{\mathrm{T}}}\right)^{\frac{\gamma-1}{\gamma}}=1088 \times\left(\frac{1}{6.62}\right)^{\frac{0.33}{1.33}}=680.70 \mathrm{~K} \\
\mathrm{~T}_{\mathrm{i} 4}=690 \mathrm{~K}
\end{gathered}
$$

Thermal power supplied by the combustion chamber: QCc

The fuel flow is neglected

$$
Q_{C C}=q_{m} c_{p}\left(T_{i 3}-T_{i 2}\right)=19.5 \times 1.13 \times(1088-622.68)=10253 \mathrm{~kW}
$$

Thermal power lost in the exhaust $Q_{\text {exh }}$

$$
Q_{\text {ech }}=\mathrm{Q}_{C C}-\mathrm{P}_{m l}-\mathrm{P}_{\text {thl }}-\mathrm{P}_{T A G}=10253-66-1042-1526.2=7618.8 \mathrm{~kW}
$$

\section{References}

Berger, M., Gostiaux, B., 1992, Géométrie différentielle: variétés, courbes et surfaces France Presses universitaires de Paris, ISBN : 2-13-044708-2.

Cormerais, M. 2007, Caractérisation expérimentale et modélisation des transferts thermiques au sein d'un turbocompresseur d'automobile, Thèse de doctorat de l'école centrale de NANTES, pp. 1-243.

Diango, A., 2010, Influence des pertes thermiques sur les performances des turbomachines. Thèse de doctorat du Conservatoire national des arts et métiers, Paris, pp. 1-244.

Kreith, F., 1967, Principles of heat transfer, Masson, [trad.] Kodja Badr-El-Dine, Université d'ALEP (Syrie), Colorado, International textbook Company Scranton, Pennsylvania, 1967. pp. 1-654.

Moreno, N., 2006, Modélisation des échanges thermiques dans une turbine radiale, Thèse de doctorat de l'École nationale supérieure d'arts et métiers, pp. 158.

Padet, J., 2005, Convection thermique et massique, Techniques de l'ingénieur, BE 8206.

Pluviose, M., 2005. Conversion d'énergie par turbomachines, Ellipses, pp. 1.277.ISBN 2-72982320-4.

Pluviose, M., 2002, Machines à fluides, Ellipses, pp. 1-276, ISBN 2-7298-1175-3.

Pluviose, M., 2005, Similitude des turbomachines à fluide compressible, Techniques de l'ingénieur, BM 468007.2005.

Pluviose, M. \& Perilhon, C.(2002). Mécanismes de conversion de l'énergie, echniques de l'ingénieur. BM 4281, 10-2002..

Pluviose , M., Perilhon, C., 2002, Bilan énergétique et applications, Techniques de l'ingénieur, BM 4283, 04.2003.

Rautenberg \& Al., 1981, Influence of heat transfer between turbine and compressor on the performance of small turbocharger, International Gas Turbine Congress, Tokyo, Asme paper, 1981. 
Ribaud, Y., 2004, Overall Thermodynamics Model of an Ultra Micro turbine, Journal of Thermal Science. 2004, Vol. 13, 4, pp. 297-301.

Sacadura, J. F., 1993, Initiation aux transferts thermiques, Lavoisier Tec $\mathcal{E}$ Doc, Vol. 4ème tirage 1993, pp. 1-439, ISBN. 2-85206-618-1.

Verstraete, T. \& al., 2007, Numerical Study of the Heat Transfer in Micro Gas Turbines, Journal of Turbomachinery. ASME, Octobre 2007, Vol.129, DOI: 10.1115/1.2720874, pp 835-841. 


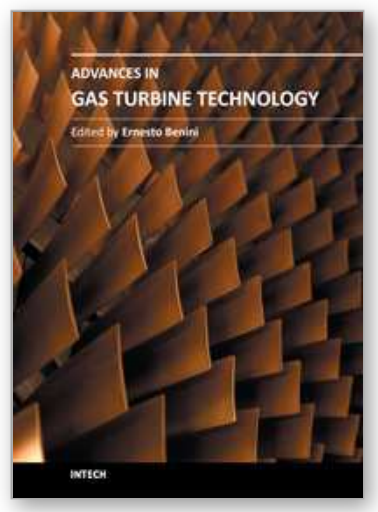

\author{
Advances in Gas Turbine Technology \\ Edited by Dr. Ernesto Benini
}

ISBN 978-953-307-611-9

Hard cover, 526 pages

Publisher InTech

Published online 04, November, 2011

Published in print edition November, 2011

Gas turbine engines will still represent a key technology in the next 20-year energy scenarios, either in standalone applications or in combination with other power generation equipment. This book intends in fact to provide an updated picture as well as a perspective vision of some of the major improvements that characterize the gas turbine technology in different applications, from marine and aircraft propulsion to industrial and stationary power generation. Therefore, the target audience for it involves design, analyst, materials and maintenance engineers. Also manufacturers, researchers and scientists will benefit from the timely and accurate information provided in this volume. The book is organized into five main sections including 21 chapters overall: (I) Aero and Marine Gas Turbines, (II) Gas Turbine Systems, (III) Heat Transfer, (IV) Combustion and (V) Materials and Fabrication.

\title{
How to reference
}

In order to correctly reference this scholarly work, feel free to copy and paste the following:

Diango A., Périlhon C., Danho E. and Descombes G. (2011). Influence of Heat Transfer on Gas Turbine Performance, Advances in Gas Turbine Technology, Dr. Ernesto Benini (Ed.), ISBN: 978-953-307-611-9, InTech, Available from: http://www.intechopen.com/books/advances-in-gas-turbine-technology/influence-ofheat-transfer-on-gas-turbine-performance

\section{INTECH}

open science | open minds

\author{
InTech Europe \\ University Campus STeP Ri \\ Slavka Krautzeka 83/A \\ 51000 Rijeka, Croatia \\ Phone: +385 (51) 770447 \\ Fax: +385 (51) 686166 \\ www.intechopen.com
}

\author{
InTech China \\ Unit 405, Office Block, Hotel Equatorial Shanghai \\ No.65, Yan An Road (West), Shanghai, 200040, China \\ 中国上海市延安西路65号上海国际贵都大饭店办公楼405单元 \\ Phone: +86-21-62489820 \\ Fax: $+86-21-62489821$
}


(C) 2011 The Author(s). Licensee IntechOpen. This is an open access article distributed under the terms of the Creative Commons Attribution 3.0 License, which permits unrestricted use, distribution, and reproduction in any medium, provided the original work is properly cited. 